\title{
The Old Kiavak Site, Kodiak Island, Alaska, and the Early Kachemak Phase
}

\author{
DONALD W. CLARK ${ }^{1}$
}

\author{
(Received 14 November 1995; accepted in revised form 4 March 1996)
}

\begin{abstract}
Excavations from 1963 on Kodiak Island, Alaska represent an early regional phase of the Kachemak tradition called "Early Kachemak" and a local phase called "Old Kiavak." Information remains insufficient to fully outline this phase of the third and fourth millennium B.P. owing to poor recovery of organic artifacts and a very sparse inventory. Comparisons with other Early Kachemak components found on Kodiak Island and elsewhere show considerable geographic variation. The Old Kiavak phase exemplifies one local phase. Radiocarbon dating indicates that occupation of the site extended back in time from approximately 2200 B.P. to 3500 B.P. No major temporal gap existed between Old Kiavak and the antecedent Ocean Bay tradition.

Evidence for technological continuity from the Ocean Bay tradition to the Kachemak tradition has been found at site AFG088 on Afognak Island of the Kodiak group. The Ocean Bay-Kachemak transition tentatively is called the Afognak phase. Radiocarbon dating indicates that this phase began slightly earlier than the Old Kiavak phase, but the two probably overlapped. The seven millennia of cultural continuity thus accorded to Kodiak Island have significant implications for the history of the northern North Pacific region and Eskimo genesis.
\end{abstract}

Key words: Kodiak Island, Alaska, Gulf of Alaska, antiquities, archaeology, Kachemak tradition, Eskimos

RÉSUMÉ. Des fouilles effectuées en 1963 dans l'île Kodiak en Alaska représentent une phase régionale précoce de la tradition Kachemak appelée «Kachemak précoce» et une phase locale appelée «Kiavak ancienne». En raison d'une faible récupération d'artefacts organiques et d'un très petit inventaire, on ne possède pas suffisamment d'information pour définir pleinement cette phase du troisième et du quatrième millénaire BP. Des comparaisons avec d'autres composants de la Kachemak précoce trouvés dans l'île Kodiak et ailleurs révèlent une importante variation géographique. La phase de la Kiavak ancienne est typique d'une phase locale. La datation au radiocarbone indique que l'occupation du site a duré d'environ $2200 \mathrm{BP}$ à $3500 \mathrm{BP}$. Entre la tradition de la Kiavak ancienne et celle d'Ocean Bay qui l'a précédée, on n'enregistre aucun intervalle de temps significatif.

Le site AFG-088, qui se trouve dans l'île Afognak du groupe Kodiak, a fourni la preuve d'une continuité technologique entre la tradition d'Ocean Bay et celle de Kachemak. On propose d'appeler la transition Ocean Bay-Kachemak la phase Afognak. La datation au radiocarbone indique que cette phase a commencé un peu plus tôt que la phase de la Kiavak ancienne, mais que très probablement les deux se chevauchent. Les sept millénaires de continuité culturelle que l'on attribue ainsi à l'île Kodiak comptent pour beaucoup dans l'histoire de la région septentrionale du Pacifique Nord et dans la genèse esquimaude.

Mots clés: île Kodiak, Alaska, golfe d'Alaska, vestiges, archéologie, tradition de Kachemak, Esquimaux

Traduit pour la revue Arctic par Nésida Loyer.

\section{INTRODUCTION}

\section{Context of Research}

During the early 1960s, the Aleut-Konyag project of the University of Wisconsin excavated several archaeological sites on Kodiak Island, Alaska (Fig. 1). Previous work on Kodiak Island had consisted primarily of Smithsonian Institution excavations and surveys done during the 1930s (Hrdlicka, 1944; Heizer, 1956). Significant excavations and surveys have been carried out in the area by numerous investigators since the Aleut-Konyag project and continue to the present time (Clark, 1992a). These investigations report a 7000-year prehistory. At the base of the sequence is the Ocean Bay tradition, which during its long span developed a distinctive ground slate industry (Clark, 1979). About
3400 B.P., Ocean Bay was followed by the Kachemak tradition, another northern North Pacific sea mammal hunting and fishing culture. In turn, Kachemak was followed about 650 B.P. by the Koniag phase that led to the historically known Koniag and Alutiiq inhabitants of Kodiak Island (Clark, 1974; Knecht, 1995). (All B.P. dates are in uncalibrated radiocarbon years. Calibrated dates are given in Table 4 and in the text where age calibration is significant to the discussion).

The Kachemak tradition was described first in the 1930s at Kachemak Bay in outer Cook Inlet by Frederica de Laguna (1934). Material from the Smithsonian excavations at Uyak Bay on Kodiak Island, also excavated during the 1930s (Hrdlicka, 1944; Heizer, 1956), is recognized as being closely related to the Kachemak Bay components. The Aleut-Konyag project provided a further basis for subdividing this tradition as it is represented on Kodiak Island.

\footnotetext{
${ }^{1}$ Canadian Museum of Civilization, P.O. Box 3100, Station B, Hull, Quebec J8X 4H2, Canada

(C) The Arctic Institute of North America
} 


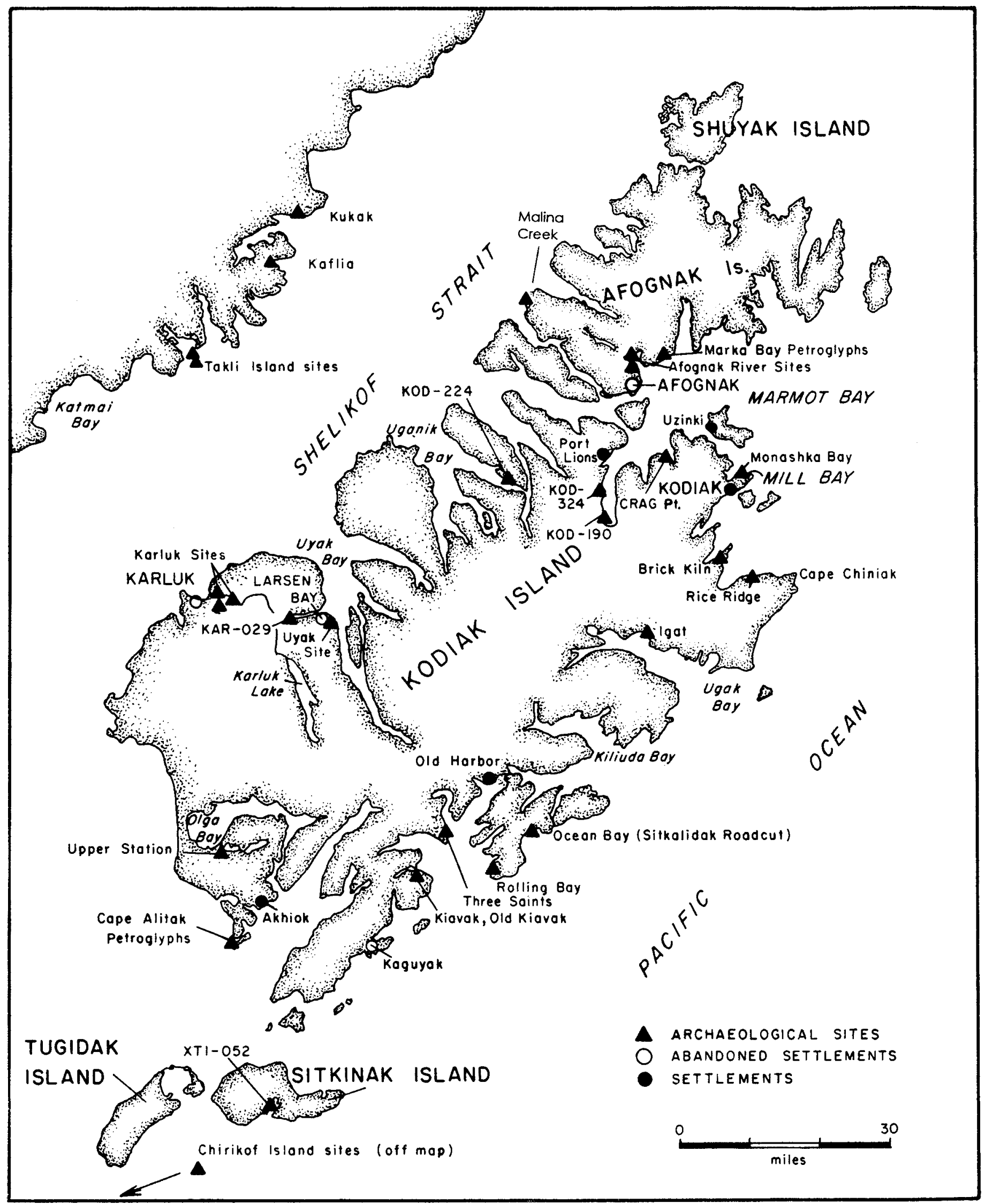

FIG. 1. Map of Kodiak Island showing the location of selected archaeological sites. 
TABLE 1. Cultural sequence on Kodiak Island ${ }^{1}$

\begin{tabular}{|c|c|c|}
\hline Date & Traditions and Phases & Characteristics \\
\hline \multirow{3}{*}{$\begin{array}{l}\text { European contact } \\
1763\end{array}$} & KONIAG TRADITION ${ }^{2}$ & \\
\hline & Historic Alutiiq & Varying degrees of acculturation according to community and period \\
\hline & Koniag Phase (Late, Developed, Early) & $\begin{array}{l}\text { Prominent woodworking industry; highly developed ceremonialism } \\
\text { Large villages and large chambered houses; focus on salmon fishing } \\
\text { Petroglyphs; pottery vessels; ground slate tools emphasized }\end{array}$ \\
\hline A.D. 1300 (700 B.P.) & Kachemak-Koniag transition & Sweat bath rubble, Koniag pottery (local) and Kachemak style artifacts co-occur \\
\hline \multirow[t]{3}{*}{800 B.P. } & KACHEMAK TRADITION & \\
\hline & Late Kachemak (regional phase) & Strong evidence of trade with mainland \\
\hline & Three Saints (local phase) & Ritual artifacts including modified human bone; art prominent \\
\hline \multirow{2}{*}{2200 B.P. } & Early Kachemak (regional phase) & Abundant fishing weights (Late and Early) toggle harnoon and labrets anpear \\
\hline & Old Kiavak (local phase) & Less elaborated than Late Kachemak; cobble industry (spall tools, etc.) \\
\hline \multirow{5}{*}{3500 B.P. } & Afognak Phase (local phase) & Ocean Bay/Kachemak transition; should represent a wider phenomenon \\
\hline & OCEAN BAY TRADITION & \\
\hline & Ocean Bay II & $\begin{array}{l}\text { Intrusive Arctic Small Tool tradition (minor) } \\
\text { Prominent ground slate industry based on linear sawn and scraped blanks. } \\
\text { Fine eyed needles suggest gut rain parkas }\end{array}$ \\
\hline & Ocean Bay I & Red ochre floors \\
\hline & Takli Alder (Alaska Peninsula) & $\begin{array}{l}\text { Flaked chert industry; microblades and slotted points } \\
\text { Stone lamps; prismatic blades }\end{array}$ \\
\hline
\end{tabular}

${ }^{1}$ Inasmuch as the sequence is essentially continuous, the criteria and dates for phase divisions may differ among researchers, as also may some of the phase names. The Ocean Bay I/II distinction centres on the strength of the ground slate industry. The long duration of Ocean Bay I is subject to partitioning, especially if earlier components become known.

${ }^{2}$ Usually referred to as the Koniag phase because of its short duration. The tradition designation is proposed for parallelism with the other traditions, in recognition of the fact that the Koniag was truncated, presumably prematurely, by historic contact, and because it is becoming subdivided into phases through further research.

The Kachemak tradition lasted 2700 years on Kodiak Island. Stylistic evidence and radiocarbon dating suggest that the Three Saints phase and Crag Point assemblages (Clark, 1970), KAR-31 or Old Karluk (Jordan and Knecht, 1988) and Uyak site components are Late Kachemak, dating from 2200 B.P. to about 800 B.P. (Table 1). Conversely, Old Kiavak is seen as a local phase of the Early Kachemak regional phase. Although Old Kiavak was excavated in 1963, no site report was issued, and the results of the excavation have yet to be fully superseded by further research. Later work has also drawn the Early Kachemak phase into a new focus in relation to northwestern North American maritime prehistory. Old Kiavak remains the principal excavated Early Kachemak component from the island. The present paper is intended to help provide an understanding of the origin and early development of one of the major building blocks of Pacific Area prehistory.

\section{Summary of Site History}

Old Kiavak (KOD-100, originally published as KOD419) is a multicomponent site, although the principal occupation there was Early Kachemak.
Hunters and fishers camped at the site as early as five millennia ago. They were responsible for the rare artifacts and charcoal streaks found in the sand below the nominal base of the site deposits.

The site contains evidence of more intensive occupation beginning about 3400 B.P. (3700 in calibrated radiocarbon years). Houses were built, and stone and clay were hauled in for hearths, ovens, and other facilities. The earliest deposits in what has been termed the "impoverished zone" contain few artifacts, and the matrix is largely sand. At the time these deposits were formed, the site probably fronted directly on Kiavak Bay. This was before the formation of the modern outer beach and intervening tidal entry (Fig. 2).

Around 3000 B.P. the intensity of occupation increased; stones, a band of kitchen midden, and more numerous artifacts were deposited. Houses continued to be built, judging from the presence of clay and stone features. Near the beginning of this period, at least one very large housepit was dug through to the base of the site.

Occupation continued through the centuries until nearly the end of the third millennium B.P., when the site was apparently abandoned. However, the site was reoccupied sometime in the first half of the last millennium B.P. The 


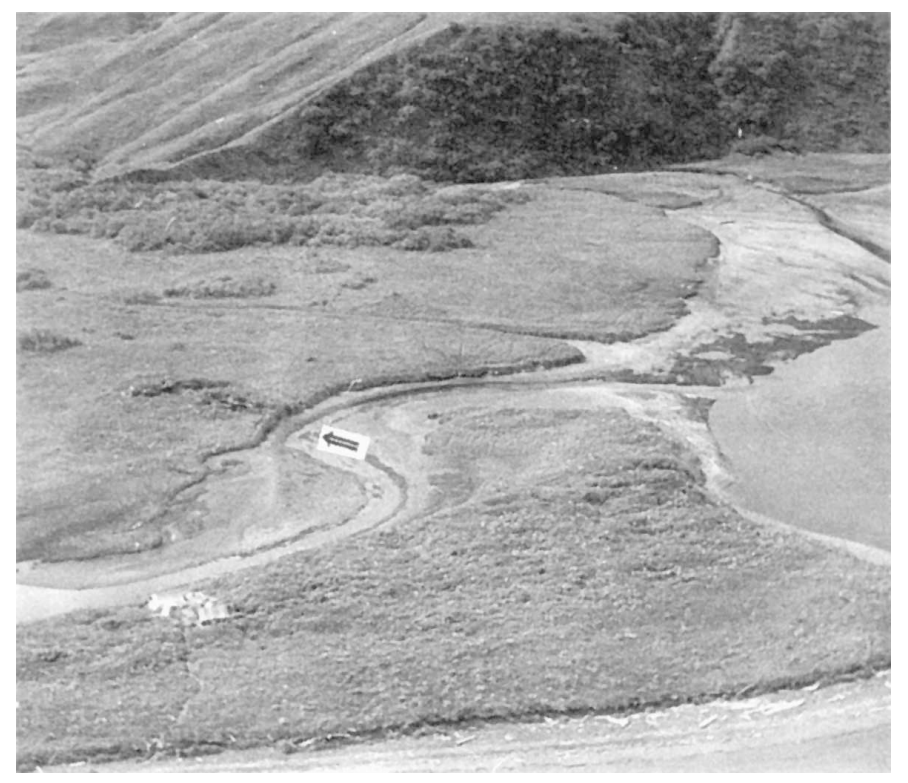

FIG. 2. The younger Kiavak site, with the Old Kiavak site in the background, from the air. The arrow indicates the location of Old Kiavik.

extent of this early Koniag occupation is not clear, because in most of the site areas Koniag deposits are not stratigraphically distinct, and there are indications of mixing with older material. Finally, about A.D. 1900 people returned and built shelters on top of the Old Kiavak mound for seasonal use. This report does not deal with the Koniag and historic occupations.

\section{The Site}

Old Kiavak is located on Kiavak Bay, $112 \mathrm{~km}$ by air southwest of the town of Kodiak, on the outer oceanic coast of Kodiak Island in the western Gulf of Alaska. The mounded portion of the site runs nearly perpendicular to the present shore and measures nearly $20 \times 50 \mathrm{~m}$. Adjoining one side is a lower area of about the same size with thinner refuse deposits. Immediately south of the site, towards the head of Kiavak Bay, a broad swift tidal channel rounds the end of a long spit that partitions the bay into a shallow inner portion and a broad, deep, outer portion. The channel localizes the movement of spawning salmon, especially pink salmon, as well as that of harbour seals that pursue the salmon. Kiavak Bay moderately indents the coast of a larger embayment known as Sitkalidak Strait, where whales, sea lions, ocean bottom fish, and seabirds would have been accessible.

Two trenches (TrA, $\operatorname{TrB}$ ) were excavated into the main mound, and an additional small test trench consisting of two $1 \mathrm{~m}$ sections ( $\operatorname{TrD}$ ) was made in the lower area. Trench A was $2 \mathrm{~m}$ wide and $24 \mathrm{~m}$ long; Trench B was $1 \mathrm{~m}$ wide, locally expanded to $2 \mathrm{~m}$, and $12 \mathrm{~m}$ long. Excavation was done by 25 $\mathrm{cm}$ levels, although attention was also given to following stratigraphic boundaries. Deposits reached a maximum thickness of $240 \mathrm{~cm}$. The matrix consisted of small fractured rocks in dark grey, soily, charcoal-laden sand. The lowest levels were especially sandy. One band of kitchen midden evidently had been dumped into a large house depression. Small patches of shell were found elsewhere, but organic preservation was very poor. Relatively pure bodies of coarse stone rubble that appeared in the upper part of the site were attributed to Koniag-phase steam baths.

The site was not as productive as had been desired, primarily because of poor bone preservation. Although the site mound looms $2 \mathrm{~m}$ above surrounding flats, the deepest part of the site is more than a metre below the highest high tide level. This depth may be interpreted as evidence of prehistoric subsidence. The sandiness of the lower Old Kiavak phase zone, coupled with the presence of deeper, charcoalstained streaks, may indicate that during the first millennia of its occupation the site was receiving large increments of sand from an adjacent beach. Low-lying flats surrounding the older site still support a growth of beach rye (Elymus).

\section{KONIAG PHASE COMPONENT}

Given the lack of separation by a clear-cut stratigraphic marker, several cautions must be followed in sorting the Koniag component from the larger whole-site collection (Table 2). A primary criterion employed here takes into account stylistic and typological differences between Koniag and Old Kiavak phase artifacts. This procedure cannot be followed slavishly, lest any intervening component having attributes of both be misinterpreted. As well, many of the most common implements, such as cobble spalls and abraders, occur throughout the Kodiak cultural sequence.

Although shallowness tends to correlate with lateness, there are indications of patchiness or unevenness of the Koniag deposits. Specimens from the top three levels ( $0-75$ $\mathrm{cm}$ ) could belong to either the Koniag or the Old Kiavak phase. The level distribution of Kachemak-style artifacts is shown in Table 3. Even in the uppermost levels, Early Kachemak artifacts have a strong presence, usually outnumbering similar items in deeper levels. Pits, now filled with varied deposits and fire-cracked rock, are interpreted here as sweatbath rubble and attributed to the Koniag phase (the rubble also could be transitional Kachemak-Koniag). Such pits penetrate the top three levels and in one case extend into Level 4 (henceforth L4, etc.; below $75 \mathrm{~cm}$ ). The Koniag occupation was probably too brief to result in the accumulation of any continuous blanket of refuse deposits. Undistinguished implements inferred to come from the Koniag component are not effectively separated from similar items in the Old Kiavak component. Therefore, these items are described jointly below. Other Koniag artifacts are of types previously reported from Kodiak and will not be further described here.

\section{OLD KIAVAK PHASE COMPONENT}

\section{Occupational or Stratigraphic Zonation}

Old Kiavak midden and stony deposits, mixed Koniag and Old Kiavak phase deposits, lenses of sweatbath rubble, 
TABLE 2. Master list of artifacts collected.

\begin{tabular}{|c|c|c|c|}
\hline Artifact & $\begin{array}{l}\text { Koniag } \\
\text { (certain) }\end{array}$ & $\begin{array}{l}\text { Old Kiavak } \\
\text { (certain) }\end{array}$ & $\begin{array}{l}\text { Undetermined } \\
\text { (either/both) }\end{array}$ \\
\hline \multicolumn{4}{|l|}{ Hunting, Fishing, Gathering } \\
\hline Toggle harpoon head & 0 & 1 & 0 \\
\hline Toggle harpoon foreshaft & 0 & 1 & 0 \\
\hline Harpoon head, nontoggling & 0 & 5 & 0 \\
\hline Ground slate points & 2 & 13 by type & 3 frag. \\
\hline Flaked points & 0 & 2 & 1 \\
\hline Notched pebbles & 0 & 109 by type & 0 \\
\hline Notched/grooved cobbles & pres. & 12 by type & 35 \\
\hline Fishhook shank & 0 & 1 & 0 \\
\hline Bone gorge or prong & 0 & 1 by type & 0 \\
\hline Clam or root digger tip & 0 & 1 & 0 \\
\hline Fishhook shank & 0 & 1 & 0 \\
\hline \multicolumn{4}{|l|}{ Tools } \\
\hline Bone wedges & 1 & 2 & 0 \\
\hline Awls and similar items, bone & 0 & 4 by level $^{1}$ & 0 \\
\hline Adze haft & 0 & 0 & 1 \\
\hline Adze bits & 3 & 8 by type/level & 3 \\
\hline Burnishing stone & $1 ?$ & 0 & 0 \\
\hline Grinding slab & 0 & 1 below base & 0 \\
\hline Stone saws & 0 & 2 & 2 \\
\hline Maul head & 0 & 0 & 1 \\
\hline Stemmed knife blades & ? rare & 26 by type/level & 19 \\
\hline Ulu blades & 2 & 16 by level & 34 \\
\hline Ground slate fragments & pres. & 39 by level & 109 \\
\hline Abrasive stones & 1 & 8 & 15 \\
\hline Hammerstones & 2 & 3 by level & 31 \\
\hline Ulu-shaped scrapers & pres. & 7 by level & 10 \\
\hline Trimmed beach shingles & 0 & 41 by type & 0 \\
\hline Boulder flakes & pres. & 22 by level & 65 \\
\hline Slate fragment scrapers & $?$ & 11 by level & 39 \\
\hline Other flaked slate blades & $?$ & 3 & 3 \\
\hline \multicolumn{4}{|l|}{ Flaked chert/greenstone } \\
\hline not classified above & 0 & 8 by level & 6 \\
\hline Ground slate splinter & 0 & 0 & 4 \\
\hline Miscellaneous & 2 & 3 & 1 \\
\hline \multicolumn{4}{|l|}{ Household } \\
\hline Lamps & 1 & 4 & 11 \\
\hline Pottery & $15.3 \mathrm{lb}$ & 0 & 0 \\
\hline Spoon fragment & 1 & 0 & 0 \\
\hline \multicolumn{4}{|l|}{ Ceremonial, Other Artifacts } \\
\hline Incised figurines & 4 & 0 & 0 \\
\hline Incised tablet & 0 & 1 & 0 \\
\hline Labret & 1 & 1 & 0 \\
\hline Grooved tooth & 1 & 0 & 0 \\
\hline Artifact Total & $22+$ pottery & 357 & 393 \\
\hline
\end{tabular}

${ }^{1}$ Assignment of an artifact to the Old Kiavak component by level generally means recovery from Level 4 or deeper.

and relatively numerous artifacts comprise the upper 100$125 \mathrm{~cm}$ of deposits. Old Kiavak artifact types also are present in the next lower levels, termed the "impoverished zone," but in very low frequency. Nevertheless, this second zone is distinguished by an appreciable number of structural features. A third zone, generally below $175-$ $200 \mathrm{~cm}$ deep, consists of charcoal-stained streaks in the sand below the nominal base of the site. An early radiocarbon date (P-1038) suggests that these streaks may be attributed to the Ocean Bay tradition.
TABLE 3. Level distribution of selected Old Kiavak phase artifacts.

\begin{tabular}{|c|c|c|c|c|c|c|c|c|c|c|}
\hline \multirow[t]{2}{*}{ Artifact } & \multirow[t]{2}{*}{ Trench } & \multicolumn{8}{|c|}{ Level } & \multirow[b]{2}{*}{ Total } \\
\hline & & 1 & 2 & 3 & 4 & 5 & 6 & 7 & 8 & \\
\hline \multicolumn{11}{|c|}{ Unifacial shingles } \\
\hline & A & 3 & 4 & 5 & 1 & 1 & 1 & 0 & - & 15 \\
\hline & B & 1 & 2 & 1 & 1 & 4 & 0 & 0 & - & 9 \\
\hline \multicolumn{11}{|c|}{ Plummets and edge-groove cobbles } \\
\hline & A & 1 & 0 & 1 & 0 & 1 & 0 & 0 & 0 & 3 \\
\hline & B & 0 & 2 & 1 & 0 & 2 & 1 & 1 & - & 7 \\
\hline \multicolumn{11}{|c|}{ Notched pebbles } \\
\hline & A & 4 & 6 & 4 & 2 & 1 & 4 & 1 & 0 & 22 \\
\hline & $\mathrm{B}$ & 7 & 13 & 11 & 13 & 0 & 0 & 0 & - & 44 \\
\hline \multicolumn{11}{|c|}{ Serrated or barbed stem point or knife } \\
\hline & A & 1 & 1 & 4 & 4 & 0 & 1 & 1 & 2 & 14 \\
\hline & B & 0 & 3 & 3 & 0 & 0 & 0 & 0 & - & 6 \\
\hline \multicolumn{11}{|c|}{ Total Number } \\
\hline & A & 9 & 11 & 14 & 7 & 3 & 6 & 2 & 2 & 54 \\
\hline & $\mathrm{B}$ & 8 & 20 & 16 & 14 & 6 & 1 & 1 & - & 66 \\
\hline \multicolumn{11}{|l|}{ Percent } \\
\hline & $\mathrm{B}$ & 12 & 30 & 24 & 21 & $\begin{array}{c}3.0 \\
9\end{array}$ & 1.5 & 1.5 & - & $99 \%$ \\
\hline
\end{tabular}

\section{Dating the Old Kiavak Component}

Several radiocarbon assays relate to the age and duration of the Old Kiavak phase component (Table 4). All samples dated are wood charcoal with one exception of charred fat scraped from pottery.

The earliest sample, P-1038, dates a charcoal streak found below the nominal base of the site. The age of $4698 \pm 71$ B.P. is well into the range of the Ocean Bay II phase.

Stratigraphically, the next oldest date is S-2997, $3375 \pm$ 255 B.P. The sample came from about $25 \mathrm{~cm}$ above the nominal base of the site.

Third in the sequence is $\mathrm{P}-1039$, comprising disseminated charcoal. This sample was collected from the base of the main zone, but possibly also from the top of the impoverished zone. The date of $3263 \pm 61$ B.P. correlates to the end of the period of rapid sand deposition.

S-2996 (1960 \pm 75 B.P.) and S-3844 (2750 \pm 130 B.P.) also come from near the nominal base of the site. The two assays are from splits of the same sample. The younger determination, S-2996, is out of sequence with the chronology established by other dates. The dates are for a disturbed hearth feature in a depression, evidently a housepit, dug into natural deposits below the nominal base of the site.

S-2998 (2400 \pm 235 B.P.) dates charcoal from a structure late within the Old Kiavak phase, near the end of Early Kachemak.

Outside the Old Kiavak site, at an Afognak River estuary site, AFG-088, an Early Kachemak component with transitional Ocean Bay aspects, proposed as the Afognak phase, has been dated to $3530 \pm 80$ B.P. and $3490 \pm 90$ B.P. (Table 4). Turning to the antecedent culture, uncalibrated dates for middle to late Ocean Bay II at Ocean Bay, Afognak, and the Rice Ridge Site (KOD-363) are $3929 \pm 65$ B.P. (P-1036), $3890 \pm 110$ B.P. (Gak-3803), 3850 B.P. (Beta 43135), and 3860 B.P. (Beta 43134) (Mills, 1994). Although the full suite of dates from Kodiak (which is not given here, and utilizes 
TABLE 4. Radiocarbon dates from the Old Kiavak (KOD-100) and Afognak (AFG-088) sites.

\begin{tabular}{|c|c|c|c|c|c|}
\hline Number & $\mathrm{Age}^{1}$ & Date Uncalibrated & Date Calibrated $^{2}$ & Samples & Application \\
\hline \multicolumn{6}{|c|}{ Old Kiavak KOD-100 } \\
\hline P-1041 & $937 \pm 49$ & AD 1013 & AD 1040 & Pottery $^{3}$ & Early ceramic Koniag \\
\hline S-2996 & $1960 \pm 75$ & $10 \mathrm{BC}$ & $28-51 \mathrm{BC}$ & Near base & Early Kachemak housepit \\
\hline S-2998 & $2400 \pm 235$ & $450 \mathrm{BC}$ & $407 \mathrm{BC}$ & Structure & Near end of Early Kachemak \\
\hline S-3488 & $2750 \pm 130$ & $800 \mathrm{BC}$ & $904 \mathrm{BC}$ & Near base & Same as S-2996 in depression that penetrates to base site \\
\hline P-1039 & $3263 \pm 61$ & $1313 \mathrm{BC}$ & $1523 \mathrm{BC}$ & Middle level & Early Kachemak at Old Kiavak \\
\hline S-2997 & $3375 \pm 255$ & $1425 \mathrm{BC}$ & $1678 \mathrm{BC}$ & Near base & Early Kachemak at Old Kiavak \\
\hline P-1038 & $4698 \pm 71$ & $2748 \mathrm{BC}$ & $\begin{array}{l}3383 \mathrm{BC} \\
3503 \mathrm{BC}\end{array}$ & Sub-base & Pre-Kachemak occupation \\
\hline \multicolumn{6}{|c|}{ Afognak AFG-088 } \\
\hline Beta- 88720 & $2780 \pm 110$ & $830 \mathrm{BC}$ & $910 \mathrm{BC}$ & Feature pit? & Old excavation to base \\
\hline Beta- 88719 & $3490 \pm 90$ & $1540 \mathrm{BC}$ & $1765 \mathrm{BC}$ & Base of site & Early Kachemak with some Ocean Bay II attributes \\
\hline Beta-77807 & $3530 \pm 80$ & $1580 \mathrm{BC}$ & $1880 \mathrm{BC}$ & Base of site & Same as Beta-88719 \\
\hline
\end{tabular}

${ }^{1}$ Before A.D. 1950, 5568 yr. standard half-life, without calibration for tree-ring based true age. Originally, several of these dates were published as before A.D. 1965 (Clark, 1966b).

${ }^{2}$ Calibrated dates are calculated from the calibrated ages in Mills, 1994 by subtracting his CALIB program ages from A.D. 1950, with the exception of the Beta Analytic dates which were calibrated by that radiocarbon laboratory.

${ }^{3}$ Charred residue, probably from sea mammal fat, with corrections and calibration adjusts to about A.D. 1400.

samples that have not been shown to apply to definitive assemblages) shows no gap in the temporal sequence, the dates cited above suggest that there may be a critical gap of about four centuries, from 3900 B.P. to 3500 B.P., for which the cultural phase attribution is unclear; but when the dates are calibrated, the one sigma ranges of the AFG-088 and Ocean Bay dates meet.

\section{Artifact Collections: Old Kiavak Phase and Items of Uncertain Phase Attribution}

Collections are described by functional categories (see Table 2).

Toggle Harpoon Head (Fig. 3f): This small, unfinished $5.7 \mathrm{~cm}$ long toggle harpoon head with blade slit is of generalized Kachemak tradition format.

Foreshaft (Fig. 3a): An unbarbed prong from the impoverished zone has a shouldered stem like that of the barbed harpoon heads. It is identified as the foreshaft for a large toggle harpoon head.

Nontoggling Harpoon Heads (Fig. 3b, c): The line would have been attached around the square-shank stem, above the bilaterally shouldered base, on the three stylistically uniform harpoon heads. Each head has a symmetrical pair of bilateral barbs.

Ground Slate Points: Eighteen ground slate projectile points were recovered. The thirteen described here are assigned to the Old Kiavak phase on the basis of their attributes and provenience.

Nine barbed points are fashioned somewhat in the Three Saints mode (Fig. 3h, i), named for its occurrence in that Late Kachemak phase. In this style, the stem has straight, parallel, carefully flattened sides and a flat or slightly concave base, and is wedge-shaped in cross-section. Barbs are symmetrical and are usually large and well undercut. The barb meets the stem at a sharp, carefully cut angle. Such points were found in most levels; however, only one point is complete, and it is damaged. One large point or lance blade has a geometric design on the blade. Two broken points were re-edged at the end, one obliquely and the other transversely (Fig. 3i).

Three unbarbed stemmed points from L1 and L4 have stems otherwise fashioned in the Three Saints mode. Some stemmed points are not especially distinctive, but their depth of occurrence indicates Kachemak tradition provenience (Fig. 3g).

From the impoverished zone there is a fragment of a very slender point originally $6.5 \mathrm{~mm}$ wide and more than $75 \mathrm{~mm}$ long (Fig. 3j). The stem is incomplete, lacking the butt end. It evidently was formed through grinding the edges flat. The cross-section is lozenge lenticular. The format is suggestive of some Ocean Bay II points (Clark, 1979: Plate 1K, 11D).

Flaked Points: A bifacially flaked basalt point, now ca. 6 $\mathrm{cm}$ long, is broken at the base but appears to have had a stem with sloping shoulders. The exact context of this specimen, recovered from the spoil, was lost.

Two bifacially flaked greenstone points were found near the nominal base of the site. The smaller point or implement tip was associated with stone slab fireboxes in section A9 (Fig. 3e). It has a pointed, single-shouldered stem (if ends are reversed, it becomes a drill), and in this respect is suggestive of an Ocean Bay I specimen (Clark, 1966a: Fig. 2B). This specimen is concavo-convex in longitudinal section, evidently reflecting bowing of the flake blank, and is slightly ground on the convex face. A larger $5.5 \mathrm{~cm}$ long specimen is lenticular in plan, but slightly rounded at one end rather than being bipointed (Fig. 3d).

Notched Pebbles: Numerous pebbles are notched at the ends, and in most cases the notches are smoothed. Customarily, notched pebbles are identified as fishnet weights. The mean length of these pebbles of just over $68 \mathrm{~mm}$ is appreciably greater than that of the Late Kachemak Three Saints (mean $58 \mathrm{~mm}$ ) and Crag Point notched pebbles (means of 

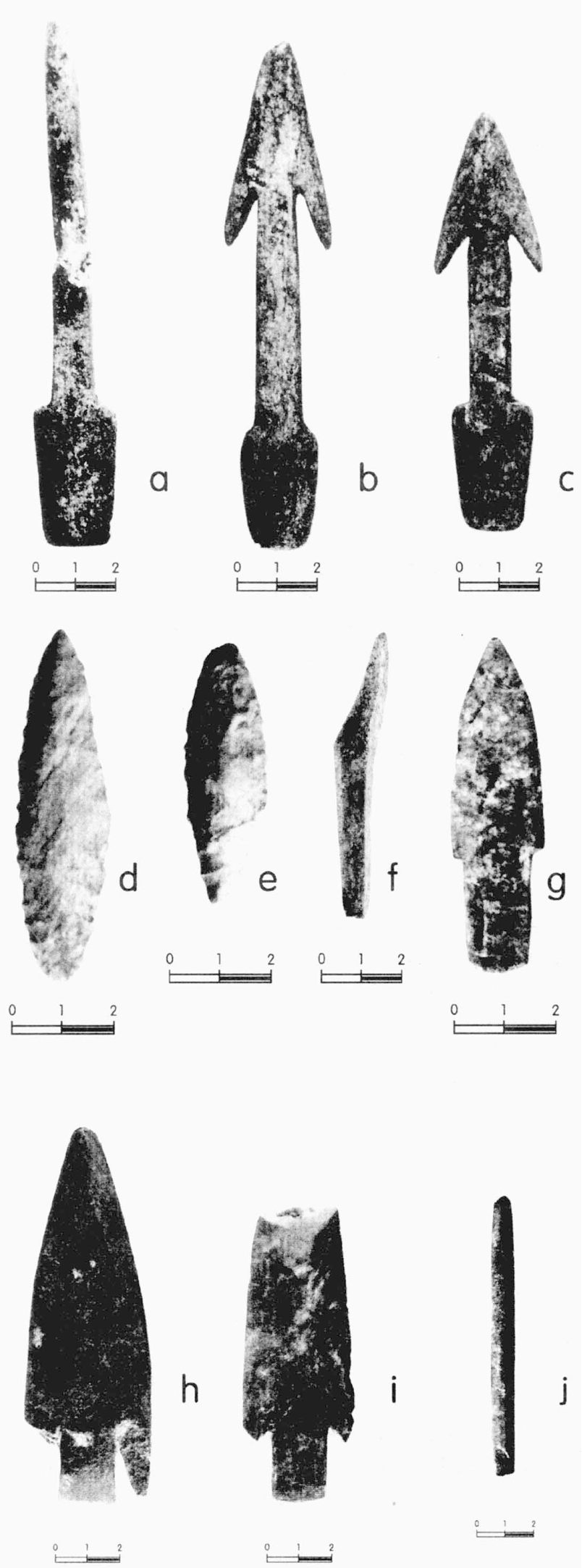

FIG. 3. Projectile points from Old Kiavak: a: harpoon foreshaft; b, c: harpoon heads; d: flaked point; e: flaked point or drill; f: unfinished toggle harpoon head; $\mathrm{g}-\mathrm{j}$ : ground slate points; $\mathrm{i}$ has reshaped ground transverse edge; $\mathrm{j}$ is slender type. various lots 54 to $62 \mathrm{~mm}$ ) (Clark, 1970). This is in keeping with a trend observed elsewhere for early specimens to be larger than later ones (de Laguna, 1934). However, there is no difference in average weight, which is $45 \mathrm{~g}$ at both Three Saints and Old Kiavak. Level distribution is given in Table 3.

Notched and Grooved Stones (Fig. 4a, b, d, e): Notched and grooved cobbles and larger pebbles are classified in Table 5. Attention is drawn to the Type 6 edge-grooved specimens, which have not been reported elsewhere in the Kodiak area. Of the total of 47 specimens, 17 or $36 \%$ are broken. Fully $60 \%$ of Type $7-7$ a specimens (Fig. 4d, e) are broken. The heavy notched and grooved stones are quite variable in size, ranging from 4.5 to $11.5 \mathrm{~cm}$ in length, and from 57 to $570 \mathrm{~g}$ in weight.

The often deep occurrence of Type 7-7a and comparative information from other sites (de Laguna, 1934:55; Heizer, 1956:42; Clark, 1970, unpubl. data) indicate that all Type 7 specimens should be assigned to the Old Kiavak phase. The other varieties are known for both Old Kiavak and later times, but Type $2 \mathrm{~b}$ characterizes Koniag phase assemblages (Clark, 1974:60-61).

Fish Hook Shank: This L7 specimen is damaged at both ends, but is clearly a worked bone implement similar in form to hook shanks of the Pacific region.

Bone Gorge or Prong: A small, bipointed bird bone splinter $3.2 \mathrm{~cm}$ long is similar to short bipointed bones from the Late Kachemak Crag Point site.

Clam or Root Digger Tip: An incomplete, bluntly pointed, slightly curved bone object from the midden band is similar to specimens from Late Kachemak sites.

Bone Wedge: Two bone wedges are ca. $7.5 \mathrm{~cm}$ long. One L5 specimen belongs to the Old Kiavak phase, while the damaged L3 specimen also shows the fine workmanship characteristic of Kachemak tradition wedges.

Bone Awls and Related Tools: Two short bird bone awls of the usual awl format, ground to a sharply pointed tip, are of deep provenience (L4-L5). An additional bird bone specimen, which has a chisel-shaped edge, came from the impoverished zone.

Adze Haft: A decaying adze haft with knobbed "handle," found $42 \mathrm{~cm}$ deep, is similar to smaller Late Kachemak specimens.

Adze Bits (Fig. 4f, h): Most of the 14 adze bits can be assigned to the Old Kiavak phase, with the exception of two Trench D specimens not described here and a large, probably Koniag, specimen.

A small bit made on a greenstone flake, found deep, measures 18 by $32 \mathrm{~mm}$.

A $10.6 \mathrm{~cm}$ long greenstone adze with carefully prepared cutting edge but roughly flaked body is similar to Koniag planing adze bits, poorly standardized and roughly prepared. Nevertheless, it comes from Old Kiavak phase deposits.

There remain five bits that conform reasonably well to what may be regarded as an Old Kiavak type. They are small, short, tabular and often bear little finishing except at the cutting edge. They range in length from 51 to $60 \mathrm{~mm}$, and in width from 30 to $43 \mathrm{~mm}$. Only one specimen is reasonably 

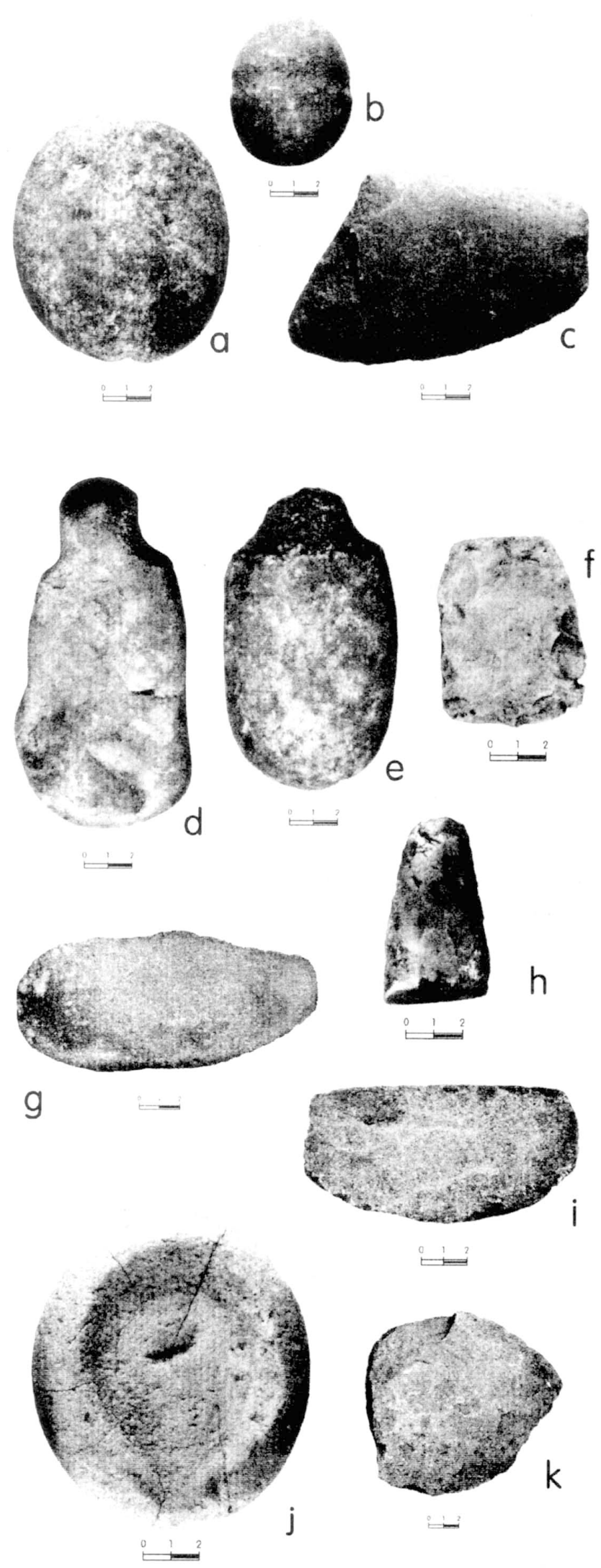

FIG. 4. Grooved stones, cobble spalls, lamp and adze bits from Old Kiavak: a: Type 2 a cobble with discontinuous end grooves; b: Type 3 pebble with short diameter groove; d, e: Type 7 plummet-type grooved stone; f, h: adze bits; c, g, $\mathrm{i}, \mathrm{k}$ : cobble spalls trimmed to shape; j: lamp. well finished by grinding on the faces and sides (Fig. 4h). It resembles small, well-made tabular Late Kachemak bits of the Three Saints phase. The others are chipped along the edges and show little facial preparation. Distribution extends from L3 into L7.

Stone Saws: One complete $7.8 \mathrm{~cm}$ long specimen and three fragmentary thin sheets of hard schistose rock are classified as saws. These have blunt, smoothed edges and are partially ground on the faces. Two fragments are double-edged. Similar specimens were recovered from the Late Kachemak Three Saints site. At least two specimens belong to the Old Kiavak phase on the basis of level provenience, which ranges from L1 to L7.

Maul Head: An ellipsoidal cobble from the top of Old Kiavak or the deepest Koniag deposits bears pecked depressions on two opposite flat sides. This $12 \mathrm{~cm}$ long specimen is broken but not battered. Comparable specimens occur in other Kachemak components.

Stemmed Knife Blades and Similar Objects (Fig. 5a-c, e, f): After probable projectile points have been segregated, there remain the double-edged blades, of which there are 19 diagnostic blades or fragments. One blade has two holes drilled near the base, 12 have serrated stems, and 4 have plain shouldered stems. Compared with projectile points, the tips of knives tend to be wide, flat, and highly convergent; the blades tend to be large and wide. Maximum width is $5.8 \mathrm{~cm}$. Their distribution peaks in L3, but they are common from L2 through L6. The tapered format of Fig. 5e is suggestive of Ocean Bay II.

Serrated-stem blades are not known from the Koniag phase on Kodiak. Thus, the fact that several were recovered from the top three levels is evidence that these levels are substantially composed of Old Kiavak phase deposits. One serrated-stem blade was found at the nominal base of the site in the impoverished zone. Similarly serrated blades are found in the Ocean Bay tradition.

Ulu blades (Fig. 5d, i): Nineteen complete blades for broad, back-hafted knives or ulus were recovered, together with 33 fragments each representing an estimated one-third or more of the blade. One deep specimen is flaked; the others are ground from slate. Compared to Koniag-phase ulus, the present blades tend to be short. The length of complete blades ranges from 6 to $14 \mathrm{~cm}$, with the exception of one $19 \mathrm{~cm}$ long specimen. Their distribution peaks in L2, but ulu blades and fragments were numerous throughout the top four levels.

Two complete and three broken specimens are perforated by drilled holes to assist their lashing to a handle. These pieces plus four other drilled fragments of slate are distributed as follows: five in L1, three in L2, and one in L4 ( 2 holes, not an ulu). Earlier ulus do not have drilled perforations. However, drilled holes are present in two deep Old Kiavak phase slate artifacts that are not ulus. All of the drilled slate pieces show a very careful technique of drilling, characteristic of but not exclusive to Late Kachemak sites (Clark, 1974), which contrasts to the rougher work seen in most specimens from Koniag sites.

Abrasive Stones: The abrasive stones consist of utilized 
TABLE 5. Notched and grooved cobbles.

\begin{tabular}{|c|c|c|c|}
\hline Type & Description & Number of Specimens & Percent of Total \\
\hline 1 & Short groove over one end & 1 & 2 \\
\hline 2 & Continuous groove girdling stone lengthwise (over ends) — long diameter & 7 & 15 \\
\hline $2 \mathrm{~b}$ & Notch or short groove over each end ( 1 has additional light notch on side) & 13 & 28 \\
\hline 3 & Continuous groove girdling stone around middle (over sides) — short diameter & 2 & 4 \\
\hline $3 \mathrm{a}$ & Like Type 3 but groove is discontinuous; intergrade between Types 3 and $3 b$ & 1 & 2 \\
\hline $3 b$ & Notches or short grooves on each side & 2 & 4 \\
\hline 7 & Grooved plummet, knob at end & 9 & 20 \\
\hline \multirow[t]{3}{*}{$7 \mathrm{a}$} & Like Type 7 but extensively sculptured at and near end to produce a neck & 1 & 2 \\
\hline & Unclassified fragments ( 1 is Type 4 ?) & 3 & 6 \\
\hline & TOTAL & 47 & 101 \\
\hline
\end{tabular}

pumice and scoria lumps $(\mathrm{n}=4)$ and flat, somewhat tabular pieces of sandstone and siltstone $(n=20)$. The tabular abraders or hones are either pieces of stone slabs that have been worn smooth or thin cobbles worn flat from use, usually on one side only. Twelve are of sandstone, and eight are of finer-grained material such as siltstone, shale, and slate. None appears to have been especially shaped about the edges. Most are fragmentary, but complete specimens evidently exceeded 8 by $10 \mathrm{~cm}$ in size. This type of artifact characterizes both the Koniag and Old Kiavak phases at the site.

Ulu-shaped Scrapers and Slate Fragment Scrapers: Nine complete ulu-shaped scrapers and eight major fragments are flaked from slate. They range in length from 6.9 to $23 \mathrm{~cm}$. One specimen appears to be a reworked piece of ground slate. Two more show traces of grinding near the edge. All have blunt edges, and in some cases the edge is quite smooth, possibly from use. This type of implement appears to have persisted from Old Kiavak times until historic contact with little change.

Boulder Flakes (Fig. 4c, g, i, k): Of 87 large cortical flakes detached from cobbles, 45 show reasonable indications of utilization. The remainder probably are rejects, or could not be examined adequately because the edge has been lost through weathering and damage. One indication of utilization is smoothing of the edge. Another is retouch for flattening or straightening the edge. Many specimens have been trimmed around part or all of the perimeter by a battering retouch. Retouch or shaping may change the outline shape from that of the original cobble spall. There is a considerable range in the sharpness and thickness of these spalls. A few boulder flakes also show traces of smoothing on the fractured (ventral) face and at the edge. A specimen from L7 (Fig. 4g) is very elongate like an adze as a result of shaping. There is some smoothing all over the ventral surface, as if the specimen had been water-rolled, but the deep provenience makes this improbable. Another spall trimmed to a linear tablet has a ground bit as seen in adzes. Length ranges from 6 to $15 \mathrm{~cm}$; the mode is $10 \mathrm{~cm}$.

This type of artifact is ubiquitous in the greater region, though its use varied from locality to locality. Extensive reshaping of the blank is a distinguishing feature of the Early Kachemak tradition at Old Kiavak.
Ground Slate Splinters: Four ground slate splinters are rectangular or irregular in cross-section. The only complete specimen is ground on two sides, while natural flat surfaces form the other sides. The ends of this $10 \mathrm{~cm}$ piece are blunt and unmodified, but one of the incomplete specimens is pointed. On another specimen, the surviving intact end is ground flat. Artifacts of this kind, often called slate awls when pointed, are known for both the Koniag and Late Kachemak phases. Provenience is L1 to L3.

Trimmed Beach Shingles (Fig. 5g, h): Numerous flaked slate tablets were produced from beach shingles. Pointedovoid, elongate pointed, and flat-based blades with rounded to gently pointed ends were carefully formed in a manner that leaves one naturally smooth side of the artifact free from chipping scars. This characteristically gives them a unifacial aspect, though sometimes both sides show cortical surfaces. The edges are thick, blunt, and usually very regular. A few specimens bear traces of grinding by which the edges were blunted and irregularities removed, but none ever was transformed into a wholly ground implement. One specimen also bears a trace of grinding on the ventral surface. These pieces do not appear to be blanks inasmuch as examples showing further stages of preparation have not been recovered. Similar tablets are not reported elsewhere.

Roughly Flaked Leaf-shaped Blades: Five reasonably complete roughly flaked leaf-shaped slate blades and one tip fragment were collected. Only the last one shows any trace of grinding. These pieces tend to be thick, and all but one are blunted along the edges. Bases range in outline from pointed to slightly rounded. Length is from 9.3 to $17+\mathrm{cm}$. This class occurs throughout the Kodiak sequence.

Flaked Chert and Greenstone Objects: Flaked projectile points were described earlier. A bifacially flaked, stemmed blade-like flake was found on the beach. A large greenstone flake knife or scraper from L3 is finely retouched along the dorsal edge. A subrectangular tabular greenstone artifact is retouched unifacially along two steep edges. Formally, this L2 item is a bevelled end scraper, a type of implement extremely rare in the region. There is one good prismatic blade, though no blade industry is documented at the site. Other flaked artifacts include the rounded end of a relatively thin biface of red-brown chert, the end of a large pointed uniface, 

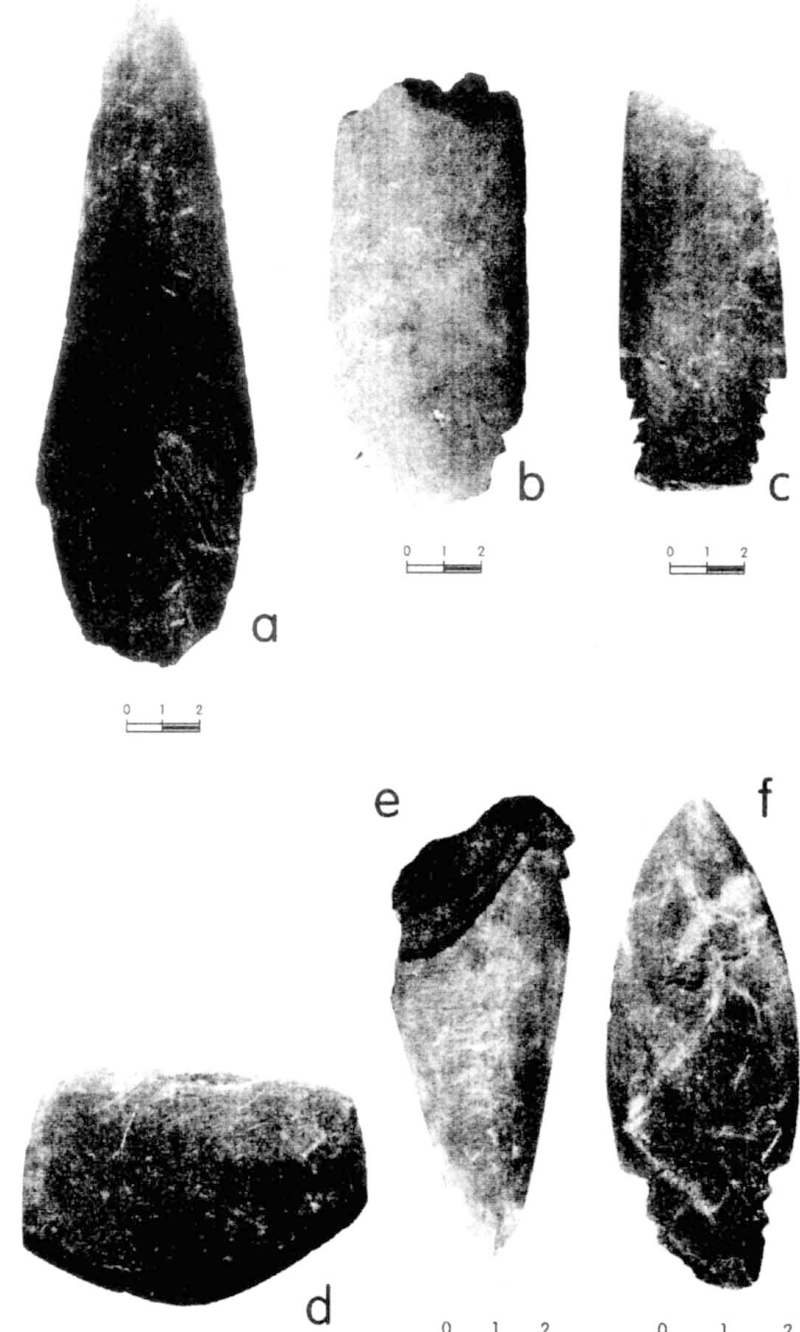

e
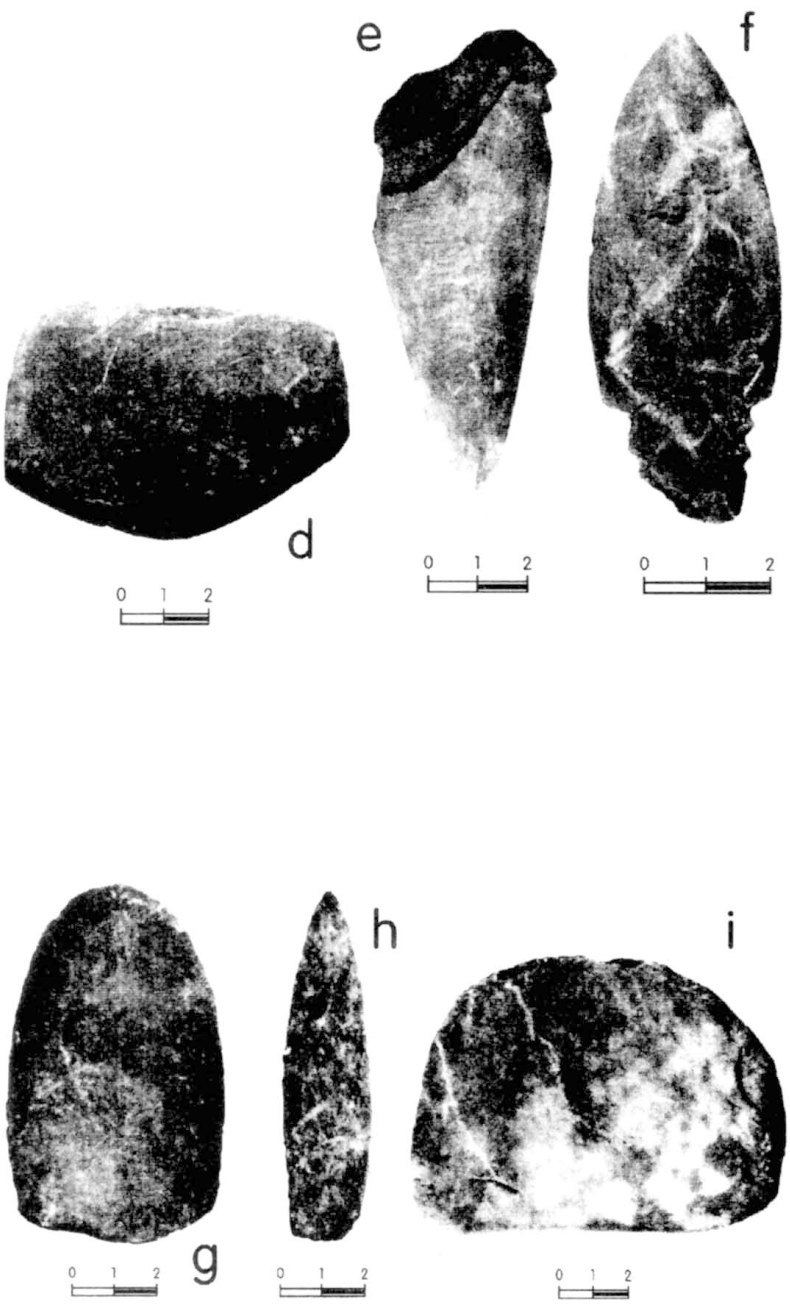

FIG. 5. Ground slate knives from Old Kiavak: a-c, e, f: stemmed knives; d, i: ulus; g, h: unifacially trimmed shingles, dorsal aspect.

and several nondescript, bifacially flaked objects, unfinished bifaces and fragments or roughly retouched flakes. A sparse scatter of greenstone flakes occurred throughout the site.
Excluding the flakes, a core chunk, and the points, the flaked chert and greenstone industry amounts to 14 implements. Including everything, there are 3 implements and 6 flakes from the top three levels, and 10 implements and 39 flakes from the remaining levels. The modest flaked chert and greenstone industry thus is most strongly represented in the deeper levels. A very low incidence of flaked cryptocrystalline stone characterizes all sites on the outer coast of Kodiak Island north to the vicinity of the town of Kodiak, except during Ocean Bay times. North of Kodiak and on Afognak Island, an appreciable amount of chert knapping took place during both Early and Late Kachemak times.

Lamps: Several stone lamps are assigned to the Old Kiavak phase. One complete lamp comes from a deep Old Kiavak context (Fig. 4j). There is also a fine, large specimen with a deep bowl from the sand streaks at the base of the site, which may have been left by Ocean Bay people more than 4000 years ago. It is similar to one from Halibut Cove at Kachemak Bay, where possible Ocean Bay tradition implements have been recovered (de Laguna, 1934: Pl. 24:4). None of these lamps show the distinct stylistic and decorative features of Late Kachemak lamps. Early Kachemak lamps commonly are of a generalized format. With the exception of one definitive Koniag specimen, and one fragment from the beach shaped on the exterior margins, these lamps consist simply of well rounded cobbles and small boulders with shallow artificial depressions. A small $7.2 \mathrm{~mm}$ long specimen appears to have been a functional lamp, as it has a capacious basin. Nearly all are made of local sandstone.

Incised Slate: A pebble from deep within the site bears a set of incised zigzag lines.

Labret: A severely eroded marble labret was recovered from Trench D.

\section{Human Remains, Burials}

A few scattered fragments of human bone were recovered from the midden refuse band, where they were found together with bones of food animals. The occurrence of broken human bones scattered within kitchen refuse deposits is characteristic of the Late Kachemak tradition (Hrdlicka, 1944; Clark, 1970). The specimens have not been analyzed, though fragments of a mandible, cranium, calcaneus, and innominate were noted. A pit at the base of the site can be identified as being from a flexed inhumation. Rotten limb bones were recognized there, but nothing was recoverable.

\section{Features}

Structural features were found at all levels of the site. Except for surface dwellings and a boulder cluster in Section A7, nearly all features are attributed to the Old Kiavak phase. The layout of features in Trench A is shown in Figure 6. The several features of A8-A10, together with certain stratigraphic layers or floors in A5-A7, are concordant and may belong to a single structure. In Trench A, most features are deep and are located within the so-called "impoverished zone." 


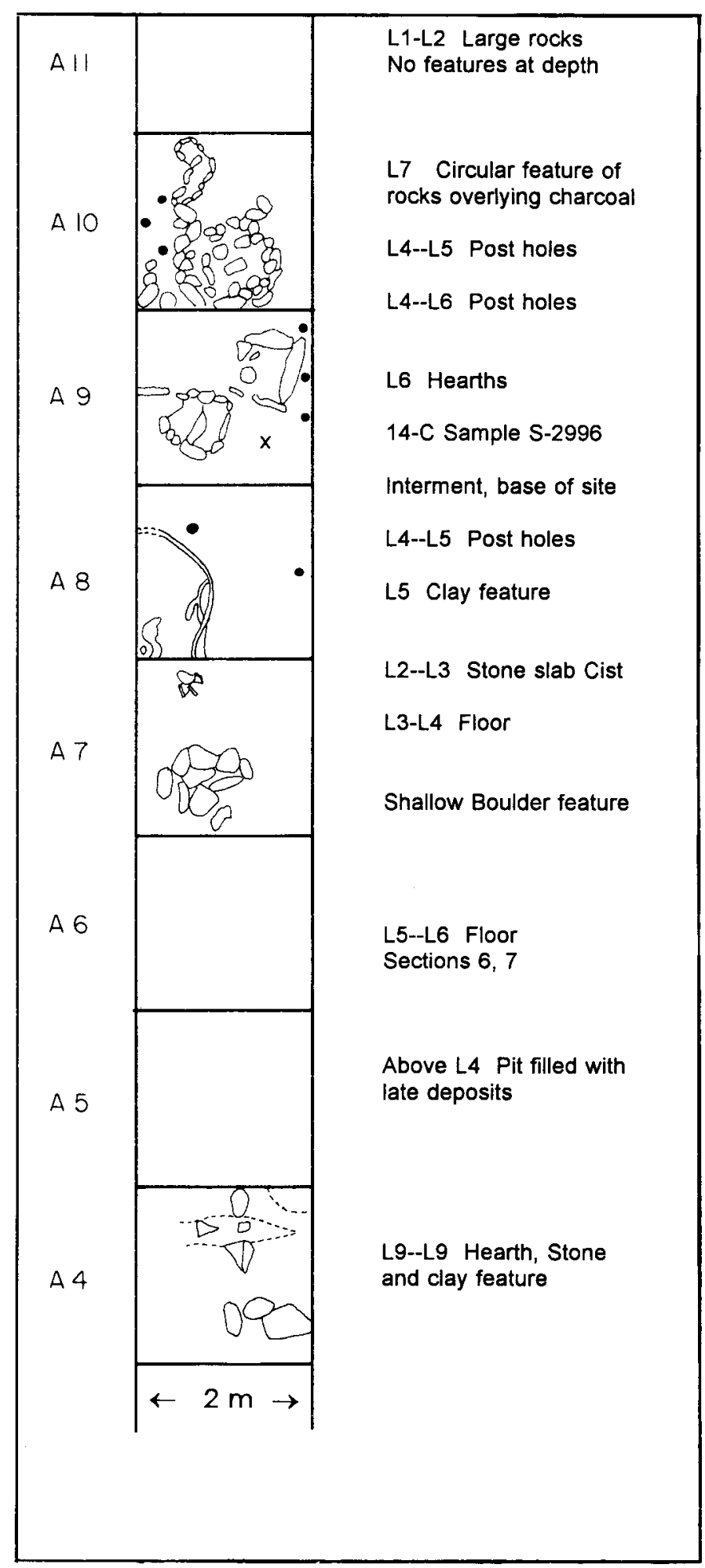

FIG. 6. Distribution of features in Trench A.

Trenching does not provide the excavation strategy suitable for recovering meaningful structural information. Many features are truncated by the excavation walls, and those that are not truncated are isolated from associated structures and features. A depression in Trench A strata appears to be a single house pit. It has a $7 \mathrm{~m}$ transect and represents a house of impressive size for an early occupation.
Circular Aggregation of Cobbles and Charcoal (Hearth?): Numerous cobbles (ca. 50) overlying charcoal were found near the base of the site in A10 (Fig. 6). Most of the cobbles lie within a circular cluster somewhat more than $1 \mathrm{~m}$ in diameter. (Field notes fail to indicate whether the cobbles had been altered by fire.) Features of this nature are often identified as hearths or roasting ovens. Hearth boxes are located nearby, at only a slightly higher elevation, in Section A9.

Hearths: Several definitive hearths were uncovered. One slab structure is a rectangular firebox. It measures $31 \times 37 \mathrm{~cm}$ inside (Fig. 6, Section A9). Only traces of charcoal occurred within the box, but masses of charcoal were found nearby. Inside the box were 10 elongate, tabular, slate beach shingles, 6 to $9 \mathrm{~cm}$ long. The second feature located in the same section, which almost touches the rectangular box, is a roughly circular, partially clay-lined construction $54 \mathrm{~cm}$ in outside diameter. Some charcoal was present inside. A large horizontal slab with adhering char partially covered the cavity. It may have been a frying surface. The rectangular box could have been used for other modes of cooking. The large circular "roasting oven" that was described earlier is located hardly a meter distant. Only traces of bones were seen in the area, and the occupants were careful not to leave implements lying about. None other than a small, flaked projectile point was found associated with these features. The floor layer is sand.

Clay Features: Clay features were found from the base of the site upwards (Fig. 6, Section A8). Clay-lined pits, depressions, and "aprons" were frequently located adjacent to hearths in the Late Kachemak Three Saints site. They have attracted attention as so-called "unfired clay pots" (Heizer, 1956:30), but other domestic or kitchen features were also formed from clay. Most have curvilinear outlines. As might be expected from their occurrence within an occupied site, these features are often truncated or severely disturbed.

\section{DISCUSSION AND CONCLUSIONS}

\section{Definition of the Old Kiavak Phase}

What distinguishes the Old Kiavak phase of Early Kachemak from Late Kachemak components as found at Three Saints, Crag Point and Karluk, other than their difference in age? Since the highlights of Late Kachemak are often in the bone artifacts, and since the Old Kiavak collection contains few organic artifacts, this question cannot be adequately answered. The following stylistic and typological differences entail common artifact attributes and types expressed in nonperishable material.

- Double-edged knife and lance blades are common in both Three Saints and Old Kiavak. However, a lugged or sideindented form of stem preparation common to the former phase is lacking in Old Kiavak.

- Another difference is the common occurrence of decorated barbed ground slate points in the Three Saints phase compared to a low incidence or absence of incised marks and decorations on Old Kiavak phase points. 
- Secondary depressions and grooves in and around the bowl are relatively common in Late Kachemak lamps, whereas Old Kiavak stone lamps are all plain. Spectacular examples of Late Kachemak lamp art sometimes are recovered.

- One of the most telling Early Kachemak indicators is the cobble grooved about one end or sculptured to a neck, here called Type 7 and 7a, or plummet-type grooved stones (Fig. 4d, e).

- Unifacially trimmed leaf-shaped beach shingles are almost unique to the Old Kiavak component.

- On the basis of Kachemak Bay finds, we expect Early Kachemak notched pebble weights to be larger than Late Kachemak ones. The Old Kiavak collection barely fits this trend; notched pebbles found there are not significantly larger than Late Kachemak examples. Nevertheless, much larger notched pebbles or shingles have been found at Early Kachemak sites elsewhere on Kodiak.

Additional tool types help fill out the description of the Old Kiavak phase (and of Early Kachemak), but are not unique to it. How to define units that are both sequential and distinctively different within what Workman (1993) terms an "elaborating tradition" is a matter for further exploration. It is its early dating and low rank within the elaborating tradition that distinguishes Early from Late Kachemak. Other regional phases have been only partially delimited (Workman, 1992). Early Kachemak, and especially the whole tradition, has a number of regional, functional, and temporal phases or variants. Old Kiavak is distinct from at least some other local phases of Early Kachemak in having a low incidence of chert and other flaked lithics, in contrast to the situation on northern Kodiak, Afognak, and Kachemak Bay (Workman, 1992; Clark, unpubl. obser.). I also note below the Afognak phase, which in a sense is Early Kachemak but differs from Old Kiavak.

\section{Early Kachemak in Space and Time}

Many apparent Early Kachemak phase sites have been found in the Pacific Eskimo region, especially in the vicinity of Kachemak Bay and the Kenai Peninsula bordering Cook Inlet (de Laguna, 1934; K. Workman, 1977; W. Workman, 1977; Workman et al., 1980; Reger and Boraas, 1993), and elsewhere on Kodiak Island. Kachemak sites, though mostly dating to the Late Kachemak phase, have also been found at Prince William Sound (de Laguna, 1956). Kachemak culture exists in a highly variant form or is amalgamated with other cultures on the Alaska Peninsula, opposite Kodiak Island. Aside from the clues provided by dating, most Early Kachemak sites are readily identified through the occurrence of one artifact type-the necked or plummet-type grooved stone. This artifact is reasonably common and readily survives at eroded sites; hence, a large number of presumed early Kachemak components have been recognized almost on the basis of it alone.
Since the latest Kachemak tradition is dated well beyond the time of the Old Kiavak Site, we will not be concerned with the upper date range. As summarized earlier, Old Kiavak radiocarbon dates suggest an occupation during the period between about 3300 B.P. (3600 B.P. calibrated) and 2200 B.P. However, artifact recovery from the lower levels is sparse, and the majority of the Old Kiavak assemblage comes from levels younger than the earliest radiocarbon dates, even from above the 2750 B.P. date (S-3488). The upper limit for the Early Kachemak component at Old Kiavak is based on extrapolation from the youngest, 2400 B.P., radiocarbon determination (S-2988) and on the fact that by about 2100 B.P., assemblages at other sites are clearly Late Kachemak in complexion.

On Kodiak Island the very earliest Kachemak dates include several from Crag Point (KOD-044) hearths not associated with house floors: 3160 B.P., 3340 B.P. More or less associated are a modest number of flaked chert artifacts, other relatively sparse generalized utilitarian artifacts, and a plummet-type grooved stone (R. Mills, pers. comm. 1993-94). The earliest dates from Crag Point and Old Kiavak are closely comparable. Other sites on Uganik Island (KOD-224) (Nowak, 1978) and at Kizhuyak Bay (KOD-324) (Crozier, 1987) have yielded slightly earlier dates, but it is not clear whether those dates apply to Ocean Bay II or Early Kachemak components. Site AFG-088, at the mouth of the Afognak River, has basal radiocarbon dates of 3530 B.P. and 3490 B.P. These are the earliest of the Early Kachemak dates and, significantly, the assemblage has some Ocean Bay II attributes: hence the proposal that it be recognized as a separate local phase. The Afognak site is a key link in the discussion below of the development of the Kachemak tradition.

In adjacent regions, only two sites date to earlier than 3000 B.P. SEW-517, dated to 3035 B.P., is a rockshelter at Prince William Sound. Its age suggests Kachemak affiliation, but artifact recovery is too sparse to establish cultural affiliation (Haggarty et al., 1991). The Uqciuvit phase component at the Uqciuvit site (SEW-056) in Prince William Sound is dated at 3380 B.P. and 3810 B.P., but may not be Kachemak. It could be Ocean Bay, but artifact recovery is too scant to establish cultural affiliation (Yarborough and Yarborough, 1993, pers. comm. 1994).

At present, no diagnostic collections from Prince William Sound have been dated very early within the Kachemak time frame. According to the Yarboroughs, archaeological and geological investigations suggest that after late Ocean Bay II times, neoglaciation precluded most of the Sound's being the seat of Early Kachemak development (see also Mills, 1994: 129-130, Fig. 4).

Workman (1993:13 and elsewhere) has noted that the Kachemak tradition is earliest on Kodiak Island. The foregoing review supports this conclusion, though, as Workman observes, the "onset and early stage" (at Kachemak Bay) are poorly dated. Earliest dating is now documented at three Kodiak Island sites (Old Kiavak, Crag Point, AFG-088) and possibly two others (KOD-224, KOD-324) where artifact associations are not clear. Kachemak dates older than 
3000 B.P. for Cook Inlet, the Seward Peninsula, and Prince William Sound are very tentative, and there are none from the Alaska Peninsula. Even in the cases of Old Kiavak and Crag Point, the artifact assemblages associated with the earliest dates are small. But in Outer Cook Inlet, including Kachemak Bay, there is a second millennium B.C. hiatus in the sequence between Early Kachemak and the Arctic Small Tool tradition (Mills, 1994: Fig. 2). When the gaps are filled, we may find that all aspects of the early phase of the Kachemak tradition were essentially coeval, wherever they occurred in the Pacific region.

\section{Two Other Early Kachemak Components}

Afognak Island: Very early Kachemak tradition occupation is documented at the mouth of the Afognak River (Workman and Clark, 1979). This attribution, made more than 20 years ago, is reinforced by the radiocarbon date of $3530 \pm 80$ B.P. (Beta-77807) obtained on a charcoal sample taken from a test pit excavated in 1994. The attribution was confirmed by a second basal sample dated at $3490 \pm 90$ B.P. (Beta-88719) from an adjacent test pit excavated in 1995. Another sample dated at $2780 \pm 110$ B.P. (Beta-88720) is interpreted as coming from a pit that penetrated the same deposits. The date also applies to the Early Kachemak phase. The original surface collection made along the shore in 1971 and subsequent surface collections come from a thin deposit that had been eroded out from under the roots of the spruce forest at AFG-088 (originally published as AFO-136). The collection, most of which had been eroded out onto the shore, numbers 966 items, of which 338 are notched stones and 372 are chert flakes and pieces of shatter.

In 1994 and 1995, I revisited the site in the context of the Afognak Native Corporation "Dig Afognak" ecotourism project and undertook three days' work that included additional surface collecting and test pitting. In 1994, a test pit was excavated in the sloping bank $2.5 \mathrm{~m}$ in from the eroded edge and progressed to $53 \mathrm{~cm}$ depth (not including $30 \mathrm{~cm}$ of Katmai volcanic ash). The pit contained Kachemak-type notched shingles, ground slate worked in the sawing and scraping techniques common to Ocean Bay II, and ulu knife blade fragments (an artifact not associated with Ocean Bay II). Further testing in 1995 confirmed the presence of an artifact assemblage that combined Kachemak and Ocean Bay attributes: notched shingles, the stem of an OB II-style slate point, and Kachemak ulu blade fragments worked by the Ocean Bay scraping technique. These in situ finds allayed fears that the surface collection was mixed.

While this collection lacks some diagnostic Early Kachemak types, the assemblage is neither distinctively Ocean Bay nor distinctively Late Kachemak. There is ample reason (even without radiocarbon dates) to identify the site as Early Kachemak with some retained attributes of Ocean Bay II antecedents; i.e., as a transitional phase which I propose to call the "Afognak" phase. The numerous notched stones are large, like the notched shingles from many other Early Kachemak sites. At $10 \mathrm{~cm}$ average length (127 g average weight for the 1994 collection) and reaching the astounding maximum of $16 \mathrm{~cm}$, they compare closely with notched shingles from Crag Point, Woody Island (Clark, unpubl. data) and de Laguna's (1934) large series from the Early Kachemak Stage II. The moderately abundant chert industry may indicate links with the antecedent Ocean Bay tradition. Nevertheless, on northern Kodiak Island, in contrast to the southeastern and southwestern parts of the island, a high incidence of chert flaking does occur in the Kachemak tradition. Heavy implements, including unformed cobble mauls, boulder flakes, and roughly flaked objects of coarse stone, characterize the AFG-088 collection, although chert artifacts and ground slate, including ulu blades, projectile points, and double-edge blades are also well represented.

A more detailed look at some of the artifacts is in order. Further details of the 1971 collection at AFG-088 are given elsewhere (Workman and Clark, 1979). Adzes are represented by numerous greenstone specimens, largely fragments. These definitely are unlike the slender, elongate, bifacially flaked Ocean Bay adzes. Some bits, including a tiny $37 \times 25 \mathrm{~mm}$ specimen, are suggestive of small Early Kachemak adzes, but others are larger and compare with Koniag phase adzes. However, the assemblage does not otherwise appear to be contaminated by any Koniag phase material. The Early Kachemak diagnostic, the plummettype grooved stone (Type 7), is not unequivocally present, but one artifact fragment appears to be of the sculptured neck variant. Flaked chert is common, but includes only a modest number of finished implements, almost none of which are diagnostic. Abundant large pieces of fire-cracked rock suggest that the Earliest Kachemak people may have had the vapour sweat bath, which contrasts with the evidence in late Ocean Bay deposits.

Considerable significance can be attached to form and workmanship in the ground slate industry. Fragments of parallel-sided sawn blanks, partially worked through scraping, have been recovered from both the beach and test pits. This is primarily an Ocean Bay II artifact type. Traces of sawing are also seen on a few other implements. Boulder spalls are smoothed at the edge in the manner of Ocean Bay saws. Moderately abundant at AFG-088 are ground slate ulu blades, an implement largely absent in Ocean Bay sites except possibly at the end of the tradition. On many ulu specimens and slate fragments, traces of an early stage of fabrication, i.e., coarse grinding and scraping, remain visible after whatever finishing was done, and erosion through beach rolling has muted manufacturing striae. Finally, turning to finished implements, the format of some ground slate points, from both shore and test pit contexts, is in the Ocean Bay II mode. Thus, Ocean Bay techniques for working slate and in some cases Ocean Bay styles of slate artifacts survive in Early Kachemak (or transitional) implements at AFG-088.

Assemblage differences might occur on a functional basis. The AFG-088 site occupies a river-mouth locality and probably was used for salmon fishing. Owing to thick ice formation, the inhabitants likely would have lived at a different winter location, on the open coast. The abundant mauls, many 
of them only cobble manuports, could have been used for installing trap or weir stakes. Nevertheless, other fishing technologies were also used. The abundant large, notched shingles are probably salmon-net weights. By way of contrast, the Old Kiavak site is situated on a bay, with access to the open ocean for sea mammal hunting, but next to a tidal inlet in some ways equivalent to a salmon stream. Thus, Kiavak could have supported year-round occupation, and the artifacts should illustrate this.

In summary, AFG-088 is significant on three counts: it is transitional Ocean Bay-Early Kachemak in a manner that indicates technological continuity of these two traditions (with presumed concomitant ethnic and linguistic continuity), which is the salient aspect of the Afognak phase and helps to explain Kachemak "origins"; it sets the beginning stage of the Kachemak tradition; and it helps to define a functional variant (salmon fishing camp) of Early Kachemak.

The Early Kachemak Type Site at Kachemak Bay: De Laguna (1934) defined the Kachemak tradition as a series of stages (or periods) at Yukon Island and Kachemak Bay on Outer Cook Inlet. Later, that definition was amplified by closely related finds on Kodiak Island. The original stages at Kachemak Bay are Yukon Island I and II, more broadly termed Kachemak I and II by de Laguna. These type components have better organic preservation than the Kodiak Island sites and thus provide information critical to describing Early Kachemak culture. The original periodization was based on stratigraphic breaks in the old or great midden at Yukon Island, corresponding to three or four changes of culture (de Laguna, 1934). For Kachemak I, the radiocarbon date reported as 748 B.C. and 756 B.C., equivalent to 2706 B.P., is somewhat equivocal, because it was obtained early in the history of radiocarbon dating and derived from specimens that had been treated with a preservative (de Laguna, 1962).

De Laguna's (1934) brief summary of culture history is quoted below:

We can briefly summarize the development of the Kachemak Bay culture by again referring to the following significant features. The stone industry of the earlier times is characterised by the greater relative importance of chipping [chert], including even the chipping of slate. The use of the stone saw is unknown. The notched stone is conspicuous by its absence [in Period I, common in Period II]; and of the grooved stones, only the type with groove about one end is found [Type 7 plummet-type]. Somewhat to our surprise, perhaps, we find realistic representation in stone already present in the First Period [stone head]. Later, polished slate grows in importance, and is applied to new types, while chipped stone becomes relatively less common. Perhaps we should associate the appearance of the felsite bar whetstone in Period sub-III with this development of polished slate. The stone saw is introduced in the same period. Notched stones suddenly appear in great numbers in the Second Period, with the large type at first predominating....Grooved stones become more numerous and there are changes in type.
Next, de Laguna discusses an early primitive-appearing harpoon head as well as traits that appear later in the sequence, such as red shale and shell beads, a variety of burial or mortuary practices, and near the end of the sequence the heavy splitting adze, copper, and rare pottery.

In many respects, the culture of the last two periods (subIII and III) was richer than that of the first, even discounting the exaggerated impression of the variety of cultural types which depends in some measure upon the large number of specimens from the Third Period. The First Period culture is simpler. (de Laguna, 1934:129-131)

Considerable variation exists between the assemblages described above, due perhaps to differences in their age over the 1700-year time span covered by the rubric "Early," to differences in site location and function, to regional variation, or simply to vagaries of sampling. I propose to group all of these assemblages, including the Old Kiavak phase, into the Early Kachemak phase. De Laguna refers to the steps in the developmental sequence as periods or stages. The term "stage" better reflects cultural-historical reality, but instead of running parallel systems of taxonomy, each with its own gloss or interpretive focus, I have limited myself to the simpler alternative. Temporal placement (early to late) is obviously an important criterion, and a certain arbitrariness has been used to set the boundary between Early and Late Kachemak. That may continue to be the case, as there are no assurances that a better archaeological record will provide more suitable markers for periodization.

Throughout this discussion, the Early Kachemak phase on Kodiak Island stands out for its simple lithic industry emphasizing relatively common or ubiquitous implements made from local material. One gets the same impression of simplicity of lithic industries from descriptions of the tradition as it existed in the outer Cook Inlet area (de Laguna, 1934; Workman, 1980). Relatively few diagnostic attributes or types characterize the durable artifact industries from the Gulf of Alaska ca. 3000 years ago. Nevertheless, small sample sizes and partial-to-complete loss of organic material have combined to give a biased and inadequate representation.

\section{The Inception of the Kachemak Tradition}

The first people known to have occupied the northern North Pacific Coast 10000 years ago are distinguished by blade and microblade technologies. Traces that old have yet to be recovered from Kodiak Island, but the first groups to occupy the island, perhaps more than 7000 years ago, can be counted among their descendants. These Ocean Bay tradition chert knappers subsequently developed a ground slate industry that formed the foundation for ground slate industries in the Pacific region of North America (Clark, 1979, 1982). Ocean Bay sites have been found on Kodiak Island, the adjacent Pacific Coast of the Alaska Peninsula, and the lower Kenai Peninsula. 
Locally on Kodiak Island, ground slate implements nearly supplanted flaked chert tools; on the northern and western parts of the archipelago, however, chert flaking continued alongside slate grinding, as it did on the adjacent Alaska Peninsula (G. Clark, 1977). The Alaska Peninsula case provides a perspective on Kodiak Island in which there is technological continuity from Ocean Bay-type coupled with change in the Takli Birch (2300-800 B.C.) and succeeding Cottonwood (A.D. 200-500) phases through most of the third millennium to first millennium B.P. Takli Birch adopted some elements that characterize the Kachemak tradition, but neither it nor the succeeding Cottonwood phase exhibit technological change away from Ocean Bay types as completely and as abruptly as that which occurred on Kodiak Island from the Ocean Bay to the Kachemak traditions. In a sense the Alaska Peninsula and Kodiak Island had separate trajectories, both derived initially from the Ocean Bay tradition. On Kodiak Island, the chronological alignment of components divides Ocean Bay and Kachemak at about 3500 B.P. (3900 B.P. calibrated).

We come, thus, to the question: what is the developmental origin of the Kachemak tradition? Is Kachemak the Kodiak Island branch of the Ocean Bay tradition, retooled and restyled? Does it stem from another people with a different ethnicity? Or is it from some combination of these possibilities? The reviews undertaken in these pages provide no basis for proposing that the Kachemak people immigrated to Kodiak and Outer Cook Inlet from other regions of Alaska. It is appropriate, then, to look for a local (Kodiak Island) development. Nevertheless, Ocean Bay II and the Old Kiavak phase are sufficiently different technologically and stylistically that there are no specific hints of any relationship between them, excepting the few artifacts noted where described, and little that indicates Kachemak developed out of the Ocean Bay tradition (Table 6).

Bridging this technological and stylistic gap requires us to assume that rapid change must have occurred during a largely undocumented period between the abandonment of the Ocean Bay II sites and occupation at Old Kiavak. Dating of the Old Kiavak deposit and late Ocean Bay, discussed earlier, allows only about five centuries for this to have taken place. But there is an additional site assemblage, the earliest Early Kachemak component, dated within this temporal range, that has transitional attributes: this is the Afognak River site (AFG-088) discussed earlier. Scrutiny of the most recent dating of Ocean Bay II assemblages also suggests that Ocean Bay may have been in transition towards Early Kachemak (Table 6, middle column). In addition, among the slate points from the Afognak site are three examples, each in a different style, that would all be at home in an Ocean Bay II slate assemblage. A few Ocean Bay II-style sawn blanks also came from AFG-088, and the scraping technique of fabrication is seen on many AFG-088 slate specimens. Several links to the Ocean Bay tradition thus are present in this assemblage, both in the surface collection and, importantly, in test pit collections associated with Kachemak notched shingles (weights) and ulu knife blades. These data strongly suggest that the Kachemak tradition developed out of Ocean Bay II about 3900 B.P. (calibrated years).

\section{Implications}

This in situ origin of the Kachemak tradition has many implications. Evidence of transition notwithstanding, the few sites thus far sampled indicate that changes from Ocean Bay to Early Kachemak occurred fairly rapidly, and this invites

TABLE 6. Contrastive elements of Ocean Bay II and Early Kachemak.

\begin{tabular}{|c|c|c|}
\hline Basic Ocean Bay II & Transitional & Basic Early Kachemak \\
\hline Sawn slate strip blanks & Present at AFG-088 & Absent \\
\hline Scraping of slate & Present at AFG-088 & Absent \\
\hline Absent & Probable fragments found late in OB II & Slate ulu blades \\
\hline Absent & Rare or absent in earliest Early Kachemak & Drilling of slate (for hafting) \\
\hline Rare & Single groove variety present & Grooved cobbles, several varieties \\
\hline Absent & & Grooved plummet \\
\hline Nearly absent & A few late in OB II & Abundant notched stones \\
\hline Absent & Rare or absent in earliest Early Kachemak & Labrets \\
\hline Absent & & Toggle harpoon heads \\
\hline Single style of harpoon head differs from Kachemak & & Several styles of harpoon, differ from Ocean Bay II \\
\hline Absent & & Arrowheads have lines outlining row(s) of barbs \\
\hline Absent & & Holes in harpoon heads (for line attachment) \\
\hline Absent & & Harpoon dart sockets \\
\hline Very long slate spear heads & & Absent \\
\hline $\begin{array}{l}\text { Edge barblets and cut-line face decorations on slate } \\
\text { spear points }\end{array}$ & $\begin{array}{l}\text { An AFG-088 point has serrated edge, stem } \\
\text { serration carries through }\end{array}$ & Absent (variant appears in Late Kachemak) \\
\hline Distinctive flaked chert points & Points may become generalized late in OB II & Generalized chert points \\
\hline Adze bits, ground on one face only, mostly flaked & & Bits ground on both faces, sometimes whole surface \\
\hline Broad stemmed slate knives & & Double-edged knives narrower and smaller \\
\hline Slit eyes in needles & [Rice Ridge data] & Late Kachemak eyes round \\
\hline Very large ochre grinders & A handstone at AFG-088 & Absent? \\
\hline Red ochre coated floors & & Absent \\
\hline Absent & & Clay-lined features \\
\hline Sea otter bones common & & Rare (not eaten) \\
\hline Absent & FCR (steam bath rubble) at AFG-088 & In some earliest Kachemak \\
\hline
\end{tabular}


speculation on causes and effects. Many changes were more than stylistic or technology transfers. For example, there appear to have been changes in hunting and fishing implements and tools, including the demise of long bayonet slate lance or spear points, the employment of net weights in great numbers, the adoption of the single-edged slate knife or ulu, and an increase in adze bit frequency. Abundant fire-cracked rock suggests that the Earliest Kachemak people might have taken up a form of steam bath. But changes in implements do not necessarily mirror changes in techniques: a short stone tip mounted in a shaft can do the same job as a long stone point alone; there are ways to weight nets without employing notched pebbles; people can split and cut fish without ulus; and adzes are not conspicuous in all archaeological cultures, though all people probably worked wood. But if there were changes in salmon fishing techniques, should we not expect concomitant changes in the organization of the fishery?

The advent of the Kachemak tradition may relate to the subsequent development of early Norton culture of the Bering Sea region-a culture with Pacific ties in its harpoon dart heads, ground slate knives, stone lamps, pebble net weights, and labrets. The finding that sawn and scraped slate persisted into the beginning of the Kachemak tradition makes it less implausible to link Choris-Norton scraped slate with early Pacific slateworking technology (Giddings, 1963:151).

This finding also illuminates our lack of understanding of the role of the Arctic Small Tool tradition (ASTt) on the Pacific Coast. ASTt artifacts appear sporadically in the very latest Ocean Bay deposits at the Rice Ridge site on Kodiak Island (P. Hausler-Knecht, pers. comm. 1990-91), and there are hints of an ASTt component at the Sitkalidak Refuge islet, where R. Knecht (pers. comm. 1995) excavated a Koniag house at the 1784 contact site. At Kachemak Bay there was ASTt settlement, probably of short duration, prior to the establishment of the Kachemak tradition (Workman and Zollars, 1982). But no trace of any ASTt influence on the Early Kachemak culture and artifact assemblages of Kodiak Island and Kachemak Bay has been recognized. Did ASTt adventurers arrive 4000 years ago, at the end of Ocean Bay time, to disappear from the region by Early Kachemak time? Did ASTt people in fact have no effect on late Ocean Bay that would be carried over into the Kachemak tradition?

Links with other regions may be seen in some early Kachemak traits, such as the broader distribution of labrets and toggle harpoon heads. It is barely known at what point these traits appeared in various areas; a fuller matrix of information is needed for both Early Kachemak and neighbouring cultures. Comparisons can be made with the Aleutian region and southeastern Alaska for the synchroneity of technology held in common, with concomitant implications of communication and relationships within the greater North Pacific region. Possibly we should have gone beyond Prince William Sound in our regional survey. There obviously was long-standing coastal communication, if not migration, in the area. For example, the ground slate industry in Hidden Falls Component II, across the Gulf of Alaska near Sitka, is specifically related to and possibly derived from the
Ocean Bay II slate industry (Davis, 1988). Although the succeeding Component III, which falls within Kachemak tradition times, has an artifact inventory that could almost be duplicated in the Kachemak tradition, the reverse does not hold: Hidden Falls III lacks most of the items that give Kachemak its distinctive character, such as grooved cobble plummets, stone lamps, and barbed ground slate points.

If, as appears to be the case, the Kachemak tradition developed out of Ocean Bay, there probably was concomitant linguistic and ethnic continuity. Most archaeologists consider Kachemak culture and people to have been Eskimoan, in the sense that Aleuts are Eskimoan, and some see them as a branch of Eskimo in the strict sense. It follows that Early Kachemak people and their Ocean Bay antecedents may have been ancestral Esk-Aleuts (Dumond, 1987a, b; Jordan and Knecht, 1988; Clark, 1992a, b), and even ancestral Eskimos. But being ancestral Eskimo does not necessarily mean being the ancestor of all Eskimos, nor does it mean that the historic speakers of the dialect of Yupiq found on Kodiak Island and the adjacent mainland have had an uncomplicated history that can be traced back in situ to 7000 years ago, or earlier. The analytic approaches of archaeology that register ethnicity and changes in ethnicity and language are not sensitive enough to allow us to make that assertion. It may be pertinent, however, that aside from some gaps in knowledge and minor extensions and contractions, the distribution of Ocean Bay, Kachemak, and Pacific Eskimo cultures has had the same boundaries for at least six millennia.

\section{ACKNOWLEDGEMENTS}

Professor William B. Laughlin had overall charge of the project in 1963 and visited it at Kiavak Bay. Crew members, in addition to the writer, were Norman Bauer, Becky Sigmon, William Workman, and Diena VanEynsbergen.

I visited the University of Wisconsin, Madison, in November 1993, to photograph the artifacts for this and other papers. My work there was facilitated by Drs. James B. Stoltman and Herbert Maschner. In 1994 and 1995, I examined additional collections in Alaska, consulted with local archaeologists, and tested and collected samples from additional Early Kachemak sites on Kodiak Island. Preparation of this report, travel, and several radiocarbon determinations have been supported by the Canadian Museum of Civilization.

\section{REFERENCES}

CLARK, D.W. 1966a. Perspectives in the prehistory of Kodiak Island, Alaska. American Antiquity 31:358-371. . 1966b. Two late prehistoric pottery-bearing sites on Kodiak Island, Alaska. Arctic Anthropology 3(2):157-184.

1970. The Late Kachemak tradition at Three Saints and Crag Point, Kodiak Island, Alaska. Arctic Anthropology 6(2):73111. 
1974. Koniag prehistory. Tübinger Monographien zur Urgeschichte, Vol. 1. Stuttgart: Verlag W. Kohlhammer.

. 1979. Ocean Bay: An early North Pacific maritime culture. Ottawa: National Museum of Man Mercury Series, Archaeological Survey of Canada Paper No. 86.

1982. An example of technological change in prehistory: The origin of a regional ground slate industry in south-central coastal Alaska. Arctic Anthropology 19(1):103-126.

__ 1992a. Archaeology on Kodiak: The quest for prehistory and its implications for North Pacific prehistory. Anthropological Papers of the University of Alaska 24(1/ 2): $109-126$.

- 1992b. Only a boat load or two: Migrations and Alutiiq prehistory. Arctic Anthropology 29(1):2-17.

CLARK, G.H. 1977. Archaeology on the Alaska Peninsula: The coast of Shelikof Strait 1963-1965. Eugene, Oregon: University of Oregon Anthropological Papers No. 13.

CROZIER, S.N. 1987. Preliminary interpretation of material remains and stratigraphy at a prehistoric site, Kodiak, Alaska. Unpubl. ms. Available at the State Historic Preservation Office, Deparment of Natural Resources, Division of Parks and Outdoor Recreation, Anchorage, Alaska, U.S.A.

DAVIS, S.D., ed. 1988. The Hidden Falls Site. Aurora: Alaska Anthropological Association Monograph Series No. 5.

De LAGUNA, F. 1934. The archaeology of Cook Inlet, Alaska. Philadelphia: The University Museum.

- 1956. Chugach prehistory: The archaeology of Prince William Sound, Alaska. Seattle: University of Washington Press. 1962. Intemperate reflections on Arctic and Subarctic archaeology. In: Campbell, J.M., ed. Prehistoric cultural relations between the Arctic and Temperate zones of North America. Arctic Institute of North America Technical Paper 11. 164-169.

DUMOND, D.E. 1987a. A reexamination of Eskimo/Aleut prehistory. American Anthropologist 89:32-56.

_ 1987b. The Eskimos and Aleuts. Rev. ed. London: Thames and Hudson.

GIDDINGS, J.L., Jr. 1963. The archeology of Cape Denbigh. Providence, Rhode Island: Brown University Press.

HAGGARTY, J.C., WOOLEY, C.B., ERLANDSON, J.M., and CROWELL, A. 1991. The 1990 EXXON cultural resource program. Anchorage: Exxon Shipping Company and Exxon Company. 339 p.

HEIZER, R.F. 1956. Archaeology of the Uyak Site, Kodiak Island, Alaska. Berkeley: University of California Anthropological Records 17(1). 199 p.

HRDLICKA, A. 1944. The anthropology of Kodiak Island. Philadelphia: Wistar Institute of Anatomy and Biology.

JORDAN, R.H., and KNECHT, R.A. 1988. Archaeological research on Western Kodiak Island, Alaska: The development of Koniag culture. In: Shaw, R., Harritt, R., and Dumond, D.E., eds. The late prehistoric development of Alaska's Native people. Aurora: Alaska Anthropological Association Monograph Series No. 4. 225-306.

KNECHT, R.A. 1995. The late prehistory of the Alutiiq people: Culture change on the Kodiak Archipelago from 1200-1750 AD. Ph.D. dissertation, Department of Anthropology, Bryn Mawr College, Pennsylvania.
MILLS, R.O. 1994. Radiocarbon calibration of archaeological dates from the Central Gulf of Alaska. Arctic Anthropology 31(1):126-149.

NOWAK, M. 1978. U.S. Fish and Wildlife Service, Archaeological Reconnaissance of Kodiak National Wildlife Refuge: JuneAugust 1977. Unpubl. ms. Available from U.S. Fish and Wildlife Service, 1011 E. Tudor Road, Anchorage, Alaska 99503, U.S.A.

REGER, D.R., and BORAAS, A. 1993. An overview of the radiocarbon chronology in Cook Inlet prehistory. Paper presented to Alaska Anthropological Association 20th Annual Meeting, Anchorage, April 1993. 8 p. Unpubl. ms. Available from D. Clark, Canadian Museum of Civilization, P.O. Box 3100, Station B, Hull, Quebec J8X 4H2, Canada.

WORKMAN, K.W. 1977. Chugachik Island: A Kachemak Tradition site in Upper Kachemak Bay, Alaska. Anthropological Papers of the University of Alaska 18(2):1-22.

WORKMAN, W.B. 1977. New data on the radiocarbon chronology of the Kachemak Bay sequence. Anthropological Papers of the University of Alaska 18(2):31-36.

- 1980. Continuity and change in the prehistoric record from Southern Alaska. In: Kotani, Y., and Workman, W., eds. Alaska Native culture and history. Senri Ethnological Series No. 4. Senri, Osaka: National Museum of Ethnology. 49-101.

. 1992. The Kachemak Tradition occupation of Kachemak

Bay: Site inventory similarities, variation and the question of settlement systems. Anthropological Papers of the University of Alaska 24 (1/2):205-227.

- 1993. Archaeology of the southern Kenai Peninsula. Paper presented to International Seminar on the Origins, Development, and Spread of Prehistoric North Pacific-Bering Sea Maritime Cultures, Honolulu, June 1993. 25 p. Unpubl. ms. Available from Department of Anthropology, University of Arkansas, Fayetteville, Arkansas 72701, U.S.A.

WORKMAN, W.B., and CLARK, D.W. 1979. The remaining 3800 years of prehistory and contact history at Afognak Bay. Appendix In: Clark, D.W. 1979. Ocean Bay: An early North Pacific maritime culture. Ottawa: National Museum of Man Mercury Series, Archaeological Survey of Canada Paper No. 86. 243325.

WORKMAN, W.B., and ZOLLARS, P. 1982. A new preface to Kachemak Bay prehistory: The basal component at SEL-033, Chugachik Island. Paper presented at the Tenth Annual Meeting of the Alaska Anthropological Association, Fairbanks. 15 p. Unpubl. ms. Available from D. Clark, Canadian Museum of Civilization, P.O. Box 3100, Station B, Hull, Quebec J8X 4H2, Canada.

WORKMAN, W.B., LOBDELL, J.E., and WORKMAN K.W. 1980. Recent archaeological work in Kachemak Bay, Gulf of Alaska. Arctic 33:385-399.

YARBOROUGH, M.R., and YARBOROUGH,L.F. 1993. Regional overview of Prince William Sound and the Pacific Coast of the Kenai Peninsula. Paper presented to International Seminar on the Origins, Development, and Spread of Prehistoric North Pacific-Bering Sea Maritime Cultures, Honolulu, June 1993. 15 p. Unpubl. ms. Available from Department of Anthropology, University of Arkansas, Fayetteville, Arkansas 72701, U.S.A. 